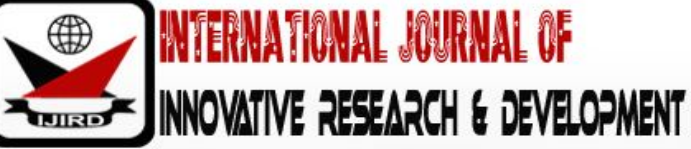

ISSN 2278 - 0211 (Online)

\section{The Role of Local Institutions in Adopting Rice Paddy Farming Technology in Duria Asi Village, Wonggeduku District, Konawe Regency, Indonesia}

\author{
Ine Fausayana \\ Dosen, Department of Agribusiness, Halu Oleo University, Indonesia \\ Wandri Tarappa \\ Civil Servant, Department of Food Crops, Horticulture and Plantation of Konawe Regency, Indonesia
}

\begin{abstract}
:
The purpose of this study was to determine the role of local institutions in the adoption of rice farming technology in Duria Asi Village, Wonggeduku District, Konawe Regency, Indonesia. Implementation time in March-May 2017. This type of research is descriptive with a qualitative approach. The results showed that the role of local institutions, namely extension workers, farmer groups and combined farmer groups at the stage of education, facilitation, consultation, and evaluation showed that these three institutions were running well. The role of poktan and gapoktan as production units, marketing units did not work well resulting in the frequent production of agricultural products in abundance in the market and prices dropped. During the consultation phase, the three institutions performed their roles well. In the evaluation aspect, the role of the instructor goes well where the evaluation process is carried out by recapitulating the production results obtained from each member of the rice paddy farmer group at the end of the harvest.
\end{abstract}

Keywords: Local institutions, rice paddy, farmer groups, combined farmer groups

\section{Introduction}

Local institutions are institutions in the locality (Uphoff, 1986) and one of the important elements in village development. Without local institutions, coupled with the bureaucracy and participants, infrastructure cannot be built or maintained. (Nasrul W, 2013). The results of the study by Hadi S and Akhmad AN (2017) conclude that the role of local institutions in encouraging economic activities in the isolated village can be built by incorporating existing local institutional elements into a systematic and cohesive development model.

In the Local Institution, the role of the extension agent is very important. Extension workers are key players in the development process (Catherine $P$ et al, 2017). No nation will have real growth in the agricultural sector without effective extension services (Anaeto F.C, 2012). To increase the capacity of extension workers, it is necessary to equip extension workers with information and communication technology (Ladelle AA, 2015). The success of agricultural development programs needs to be supported by the quality of the human resources through agricultural counseling, with the empowerment approach of farmer groups and their families and combined farmer groups to be able to manage their farming professionally and have an agribusiness perspective (Faqih A, 2014).

Extension teaching is dealing with the conveyance or passing across of new skills, technology, techniques or new methods of production in agriculture that will ultimately improve the living standard of the target audience. To be successful in technology transfer, extension worker must understand the farmers learning needs, problems, priorities, and opportunities as well as psychological process, semantic, physical and economic barriers to adoption (Aremu P.A et al 2015). The role of extension in the 21st century should be that of the sustainers, catalysts, an agency of empowerment, human infrastructure, contextualizes synergists', and collaborators. Extension services should also re-appraise its work periodically and modify its programs to suit the changing conditions (David MM and Samuel HS, 2014).

In addition to extension workers, farmer groups and a combination of farmer groups also have a role in the application of agricultural technology (Nuryanti S and Swastika DKS, 2011). Combined farmer groups (Gapoktan) is a collection of several farmer groups that join and collaborate to improve the scale of economies and business efficiency. The results of research from Indrawati NN (2015), that the Gapoktan functionis as a provider of credit, marketing results and eradicating plant pests and diseases.

\section{Research Methods}

Paradigm, Type, and Approach to Research. The paradigm of this research uses the post-positivism paradigm which is a qualitative research that presents the framework of the content of research on the role of local institutions, and the behavior of farmers in the adoption of rice paddy planting system technology. This type of research is descriptive. The 
approach used is qualitative researchwhich is a method to explore and understand clearly by describing several social phenomena that occur in lowland rice farming in Duria Asi Village, Wonggeduku District, Konawe Regency

\subsection{Location and Time of Research}

The determination of the location of the study was determined based on the potential and conditions of agriculture and the role of local institutions in the research area. This research was conducted in March-May 2017, in Duria Asi Village, Wonggeduku District, Konawe Regency, which is one of the center'sproducers of high rice production in Konawe Regency.

\subsection{Source and Data Type}

Sources of data in this study were collected from interviews with a number of informants. Informants are lowland rice farmers as the main actors who have a lot of experience, knowledge, and skills in applying system technology to lowland rice farming and members of farmer groups and a combination of farmer groups in Duria Asi Village.

The data used in this study include primary data and secondary data. Primary data, namely data obtained through in-depth interviews using a questionnaire. Secondary data is the data that becomes the support in this study which is obtained from the results of the literature review.

\subsection{Data Analysis Technique}

Data from interviews, field notes, and other finding materials were analyzed qualitatively by stages, namely analyzing the role of farmer groups as a mediumof collaboration, a combination of farmer groups as a marketing business unit and the role of extension workers in the adoption of cropping system technology in stage (a) education, (b) facilitation, (c) Consultation and (d) evaluation.

\section{Results and Discussion}

\subsection{The Role of Local Institutions in the Education Stage}

\subsubsection{The Role of Extension}

The implementation of extension activities as a learning process to members of farmer groups was seen from the implementation of the schedule of extension activities, weekly meetings of farmers with extension workers, the presence of farmers following counseling, solving farming problems and the involvement of farmers in agricultural extension. The intensity of the implementation of an agricultural extension to farmers in the lowland rice field has been reduced, the schedule of activities that have been made is no longer agreed upon, weekly meetings with extension workers are not working properly, the level of attendance of the lowland rice farmers in participating in the extension is reduced.In the education phase members of the farmer, the groupis less active in following the learning process carried out by local extension workers, due to the lack of awareness of farmers on the importance of learning in farming rice fields. This condition is caused by the attitude factor of farmers who have not experienced changes, so they have not been able to decide the right attitude in solving the problems at hand.

In connection with the lack of intensity of agricultural extension, the extension as a system basically aims to convey information about new innovations in such a way that there is a change in knowledge, skills, and attitudes of the main actors in cultivating paddy fields, then agricultural extension worker apply extension methods in the form of individual visits to members rice field farmer groups to see first hand the developments, problems that occur and efforts to resolve various problems that occur in the rice field location, through this method the learning process is participatory and dialogical can run well because the members of the farmer group feel comfortable, the process of dialogue between members of the farmer groups and extension workers run well, there is no limiting distance between the two so that a harmonious atmosphere is created in conveying information on innovation or in answering any problems encountered in cultivating rice fields.

\subsubsection{The Role of Farmer Groups}

In order for the teaching and learning process to take place properly, farmer groups are directed to have the ability to explore and formulate learning needs. Based on the conditions in the study area, it was shown that the farmer group meeting held by local agricultural extension workers had not run optimally due to various farming activities that were cultivated simultaneously.

The implementation of learning in farmer groups is carried out based on learning plans that have been compiled every year. In the study area, the learning process in the farmer group has not been going well because among the members of the farmer group has not been able to collaborate with information sources both from extension workers, work partners and from related institutions needed in the teaching and learning process. The role of the facilitator is needed to provide understanding to the members of the farmer groups about the benefits of collaborating with fellow farmers, advisory institutions and other parties as sources of information needed in the learning process to solve the problems of rice farming.

\subsubsection{Role of Combined Farmer Groups (Gapoktan)}

Combined farmer groups in carrying out their functions as a production unit develops rice field farming continuously with the target of achieving production as much as possible by paying attention to the quality of grain to have high economic value. The quality standard of grain that will be milled or stored is determined by the moisture content of 
the grain and the level of dirt. Grain moisture content of $14 \%$ is the optimum moisture content to be milled because it produces the smallest broken rice compared to the higher and lower grain moisture content. In general, the quality of grain is determined based on qualitative requirements and quantitative requirements. Qualitative requirements, which are free of pests, free of foul odors, acids or other foreign odors, free from signs of chemical substances that are harmful both visually and organoleptically and quantitative requirements. Grain Quality Requirements can be seen in table 1 below:

\begin{tabular}{|c|c|c|c|}
\hline No & Description & Quality B* & Quality C \\
\hline 1. & Moisture content (\% max) & 14 & 14 \\
2. & Empty grain/ dirt (\% max) & 3 & 3 \\
3. & Whitewashing grain/ green grain (\% max) & 5 & 10 \\
4. & Yellow grain/ broken grain (\% max) & 3 & 3 \\
5. & Red grain (\% max) & 3 & 3 \\
\hline
\end{tabular}

Table 1: Grain Quality Requirements

*Bulog in Principle Only Buys B Quality Grain, the Purchase of C Quality Grain Must Be Authorized by Kabulog

Drying is one of the important activities in the effort to maintain the quality of grain. The moisture content of freshly harvested grain ranges from $20-25 \%$, so the moisture content needs to be reduced by drying until the grain reaches a maximum moisture content of $14 \%$. Drying of grain is generally done by utilizing the sun's heat for $2-3$ days in good weather. Too long drying can result in a lot of grain breaking during milling. But if harvest occurs during the rainy season it is advisable to use an artificial dryer such as a drying machine (drayer)

Farmer groups as production units have not carried out their functions properly so that members of lowland rice farmers who are members of it do not yet know the standard quality of grain that is good in order to have high economic value or high selling prices. Because of the lack of understanding of farmers about good grain quality standards, it is necessary to have a collaborative relationship between farmer group managers and extension workers or more competent parties such as Bulog by socializing grain quality standards and the need for increased consultation to all relevant parties.

\subsection{The Role of Local Institutions in the Facilitation Phase}

\subsubsection{The Role of the Agricultural Extension Worker}

The success of paddy farming is inseparable from the intensity of mentoring extension workers to members of lowland rice farming groups in fostering and facilitating farmer group members so that they can develop a farming plancorrectly and in accordance with farmers needs. The involvement of extension workers in assisting and guiding members of farmer groups can be seen during the preparation of group program planning through the preparation of the Group Definitive Plan (RDK) and the Definitive Plan for the needs of the Group (RDKK).

The Group Definitive Plan is prepared for planning the activities of group farming development, including the need for agricultural production facilities, within a period of one year. The Definitive Plan for Group Needs (RDKK) is prepared to refer to the RDK of each group of farmers. The role of extension workers in the preparation of the RDK and RDKK is to guide paddy rice farming communities so that they can understand the type of commodity to be cultivated, provide an explanation of the use of seeds, fertilizers, and pesticides. The drafting of the definitive group plan (RDK) was carried out by holding a meeting of farmer group managers who were accompanied by agricultural extension workers in the framework of preparation of the RDK preparation with the scope including: a) evaluation of the implementation of farmer group activities in the previous year, b) evaluation of production and average productivity achieved by group members, and c) plan for drafting the RDK / RDKK. In group meetings farmers are led by the head of the farmer group, accompanied by agricultural extension workers, with scope including: a) identifying potential and problems in farming development; b) determine the type of commodity to be cultivated and the target of production; c) discuss cropping patterns/ farming patterns, needs of production facilities and technologies to be used; d) plan the activities of other farmer groups, for example irrigation improvement movements, eradication of Plant Disturbing Organisms (OPT), capital fertilization, etc .; e) organize and compile a division of labor; and f) compile and agree on the RDK of farming activities. The results of the meeting became a guideline for members of farmer groups to organize their farming activities.

\subsubsection{Role of Farmer Groups}

Farmer groups (Poktan) are a place to provide services to all members of farmer groups to meet the needs of production facilities (fertilizers including subsidized fertilizers, certified seeds, pesticides, etc.) and agricultural machinery, both based on credit / farming capital for members of farmer groups who need it or from farmers' / remaining company results. As a production unit in the farmer group shows that it is necessary to prepare the planning of production facilities needs of each member of the farmer group to support the success in cultivating paddy fields. This condition is not in line with the expectation that the Poktan function as a production unit has not run as it should. This is due to a lack of awareness and understanding of the importance of the Poktan function in lowland rice farming. The impact is that every planting season of paddy rice in the research area always does not use certified seeds, the occurrence of the scarcity of subsidized fertilizer and farming machinery processing facilities are always a problem of every season.

The role of farmer groups as production units has not gone well. The level of awareness of members of farmer groups about the importance of using quality seeds and the lack of capacity of Gapoktan in developing work plans in groups must be treated continuously. 


\subsubsection{The Role of Combined Farmer Group}

The combined function of farmer groups (Gapoktan) as a marketing business unit is strived to be able to identify, analyze market potential and opportunities based on the resources they have to develop commodities in order to provide more optimal business benefits for members of the farmer's group incorporated in it. Problems that occur in the field do not function Gapoktan institutions as marketing business units so that market opportunities for many market needs are unknown to group members, commodity development does not occur because it is focused on commodities that have been cultivated. This is due to the understanding of farmers that market opportunities are still very lacking.

Gapoktan's role in facilitating farmer group members as a marketing business unit has not been able to identify, analyze market potential and opportunities. Lack of understanding of institutional functions as gapoktan becomes a factor causing the inability of the marketing business unit in Gapoktan. The role of Gapoktan as a marketing unit is not going well because the lack of knowledge of Gapoktan officials in accessing market information to Poktan and Gapoktan members has resulted in the frequent production of agricultural products in abundant markets and prices have dropped.

\subsection{The Role of Local Institutions during the Consultation Stage}

\subsubsection{The Role of Agricultural Extension Workers}

Consultations conducted between agricultural extension workers and members of farm groups in the study area are not much different from the facilitation process, which helps solve problems or provide alternative solutions to problems in farming rice. The consultation process can run well because it is not limited to time, when, and where the consultation process between farmer members and extension workers can be done, if the extension workersare not in the location when there is a problem that must be addressed immediately then the consultation process can be done through a communication device/ telephone. In addition to capital problems in lowland rice farming, members of farmer groups also often experience problems with scarcity of fertilizer. The impact of the scarcity of fertilizer resulted in decreased rice production.

The consultation process between the main actors and agricultural extension workers went well, but the problem lies in the lack of cooperation between partners and lowland rice farmers where there is no cooperation agreement with fertilizer partners, to bring fertilizer to the target location on time. Problems arise when there is a lack of supervision in fertilizer distribution resulting in delays in supplying fertilizer to the target location. On the basis of the preparation of subsidized fertilizer RDKK that has been made by members of the farmer groups, the local extension workers recommend that members of the farmer group coordinate with existing fertilizer distribution agents in the research area, so that members of the farmer group know and understand the causes of fertilizer shortages.

The intensity of the presence of extension workers in the field can be a good motivation for members of lowland rice farmers. Awareness of extension workers is needed on the importance of mentoring to members of farmer groups, especially in the process of consultationin dealing with the problems of rice farming.

\subsubsection{Role of Farmer Groups (Poktan)}

The preparation of farming planning is one of the efforts carried out to support changes in rice farming. The farming plan is carried out through deliberation so that an agreement is reached which is beneficial for all members of the farmer group. Farming planning includes the use of quality seeds, fertilizers, pesticides and land processing machines. The problems faced by members' awareness of the importance of compiling a farming plan are still lacking so that the farming plan is carried out if it is to do the next planting.

Farmer groups as a medium for collaboration show that farmer group collaboration with other farmer groups is going well, this can be seen from the social service carried out jointly before the activities begin, namely cleaning the water channel and after harvest in terms of farming road improvements.

The ability of farmer groups to collaborate and partnering with other parties to support the rice farming that they manage is one of the efforts that continue to be encouraged in the farmer group. Problems faced in the field are the absence of cooperation agreements between farmer groups and their partners as a provider of means of production, processing, marketing of products and or capital so that members of farmer groups often experience problems in cultivating paddy fields. The problem in the field is that there is no binding agreement between farmer groups and their partners so that the prices of agricultural products in Duria Asi Village are easily mocked.

\subsubsection{Role of Combined Farmer Groups (Gapoktan)}

Gapoktan as a farming unit is strived to facilitate the application of farming (materials, tools, ways) technology in accordance with the planned activities of a group of farmers (gapoktan) problems in the research area, namely the lack of knowledge and skills of group members in implementing farming technology facilities/planting machine tools (transplanter machines) .

In the aspect of consultation, the role of extension workers, the role of farmers group and the combined role of farmer groups are going well where these three institutions carry out their respective roles in accordance with their duties as institutions that protect their members in conducting rice farming. Cooperation is needed between the management of farmer groups and the combined farmer groups to work partners in order to have a farming agreement in marketing agricultural products in order to increase income better. 


\subsection{The Role of Local Institutions in the Evaluation Phase}

Through agricultural counseling, paddy rice farmers get direction and motivation as well as good farming methods to increase rice production. Farmers' readiness before lowland farming activities begins with member meetings to determine processing time, what seeds will be used and planting time. Field conditions indicate that farming technology information, especially in planting paddy rice by using a transplanting system of jajarlegowo (Fausayana I and Tarappa W, 2018), farmers feel confident that they can produce better production compared on using other planting systems such as transplanting tiles systems and direct sowing system,

During on-going, monitoring activities. The level of knowledge, skills, and attitudes of the main actors in farming in rice fields is seen in terms of their ability to conduct their farming effectively and efficiently and their success in tackling problems both technically and non-technically. Technical ability in terms of its ability to prepare and use quality seeds, cropping patterns and planting systems, fertilization and control/ eradication of pests/diseases in lowland rice plants. Non-technical is seen from its ability to prepare and use agricultural machinery to process its farming.

After the activity is complete (sumative, ex-past). Evaluation activities are activities to compare the results and impacts achieved with the planned results and impacts of each activity and all extension activities. The purpose of the evaluation is to get an overview of the results and benefits of extension activities needed to plan future extension activities aimed at obtaining feedback to improve the implementation of the activities that are being implemented and improve the quality of future extension plans.

In the evaluation aspect, the role of the instructor goes well where the evaluation process of farmer group development is done by recapitulating the production results obtained from each member of the rice paddy farmer group at the end of the harvest. Is the result of products produced in accordance with the planned target or not. If production is in line with expectations, then it can be planned in the next program whether to increase production targets or not, if production is not in line with expectations, then through this evaluation will be seen from which aspects cause a decrease in production so that it is not in accordance with the planning to be achieved.

The Role of Local Institutions in Duria Asi Village in the Education, Facilitation, Consultation, Evaluation, and Consultation Steps can be seen in table 2 below:

\begin{tabular}{|c|c|c|c|}
\hline Institution & Role & Function & Does Not Work \\
\hline Extension workers & Education & $\checkmark$ & $\checkmark$ \\
Poktan & & & $\checkmark$ \\
Gapoktan & & $\checkmark$ & $\checkmark$ \\
\hline Extension workers & Facilitation & & \\
Poktan & & $\checkmark$ & \\
Gapoktan & & $\checkmark$ & $\checkmark$ \\
\hline Extension workers & Consultation & $\checkmark$ & $\checkmark$ \\
Poktan & & & $\checkmark$ \\
Gapoktan & Evaluation & & $\checkmark$ \\
\hline Extension workers & & & \\
Poktan & & & \\
Gapoktan & Production & & \\
\hline Extension workers & Infrastructure Unit & & \\
Poktan & & & \\
Gapoktan & & & \\
\hline
\end{tabular}

Table 2: The Role of Local Institutions in Duria Asi Village in the Stage of Education, Facilitation, Consultation, Evaluation and Consultation

\section{Conclusion}

The role of local institutions, namely extension workers, farmer groups and combined farmer groups, at the stage of education, facilitation, consultation, and evaluation shows that these three institutions are running well. In the facilitation/ accompaniment stage, in fact, the role of extension workers is better in the field. Assistance in the preparation of the RDK and RDKK has an impact on the level of knowledge and understanding of farmers on the required product facilities. The role of poktan and gapoktan as production units, marketing units did not work well resulting in the frequent production of agricultural products in abundance in the market and prices dropped. During the consultation phase, the three institutions performed their roles well. Cooperation is needed between the management of farmer groups and combined farmer groups to work partners in order to have a farming agreement in marketing agricultural products. In the evaluation aspect, the role of the instructor goes well where the evaluation process is carried out by recapitulating the production results obtained from each member of the rice paddy farmer group at the end of the harvest, from the products produced it is used as material in the subsequent program evaluation.

\section{References}

i. Anaeto F.C., Asiabaka C.C., Nnadi F.N, Ajaero J.O,Aja O.O, Ugwoke F.O, Ukpongson M.U,Onweagba A.E. 2012. The role of extension officers and extension services in the development of agriculture in Nigeria. Wudpecker Journal of Agricultural Research Vol. 1(6) : 180-185. 
ii. Aremu P.A., Kolo I. N.,Gana A.K.,Adelere F. A. 2015. The Crucial Role of Extension Workers In AgriculturalTechnologies Transfer and Adoption. Global Advanced Research Journal of Food Science and Technology. Vol. 4(2) : 014-018,

iii. Catherine P. Msuya, Festus K. Frempong A, Margaret N et al, 2017. The Role of Agricultural Extension In Africa's Development, The Importance Of Extension Workers And The Need For Change. Int. J. Agr. Ext. 05 (01) 2017. 5970

iv. David MM and Samuel HS. 2014. The Role Of Agriculture Extension In The 21 Century: Reflections From Africa. International Journal of Agricultural Extention 02(01) : 89-93

v. Faqih A, 2014. The Role of Agriculture ExtensionWorkers (Ppl) Activity Empowerment Group In The Performent of The Farmer Group. Jurnal Agrijati. Vol 26 (1) : 41 - 60.

vi. Fausayana I., Tarappa W. 2018. The Technology Adoption of Jajar Legowo System and Direct Seeding System on Rice Farming in the Village of Duria Asi, Wonggeduku District of Konawe Regency, Indonesia. The International Journal of Business Management and Technology. Vol 2 (4) : 28 - 33.

vii. Hadi S, Akhmad AN, 2017. InstitutionalRole of LocalEconomicDevelopmentInVillageIsolatedJember. Agritrop Jurnal Ilmu-Ilmu Pertanian : 211 - 217. jurnal.unmuhjember.ac.id/ index.php/ AGRTROP/ article/ .../ 593.

viii. Indrawati NN, 2016. Fungsi Gabungan Kelompok Tani (Gapoktan)Bagi Petani Desa Pojokkulon Kecamatan Kesamben Kabupaten Jombang. AntroUnairdotNet, Vol.5 (2) : 335 - 348.

ix. Ladele AA, Chris O. Igodan CO, Agunga R, Fadairo OS. 2015.Extension In Nigeria's Transformation Agenda: Key Recommendations Based on A Field Study. International Journal of Agricultural Extension. International Journal of Agricultural. Extention. Volume 03 (03) :173-185.

x. Nasrul W, 2013. Peran Kelembagaan Lokal Adat Dalam Pembangunan Desa. Jurnal Ekonomi Pembangunan. Vol 14 (1) : 102-109.

xi. Nuryanti S and Swastika DKS, 2011. Roles of Farmers' Groups in Agricultural Technology Adoption. Forum Penelitian Agro Ekonomi. Vol 29 ( 2) : 115 - 129

xii. Uphoff. 1986. LocalInstitutionalDevelopment:AnAnalytical SourcebookWithCases.KumarianPress. 